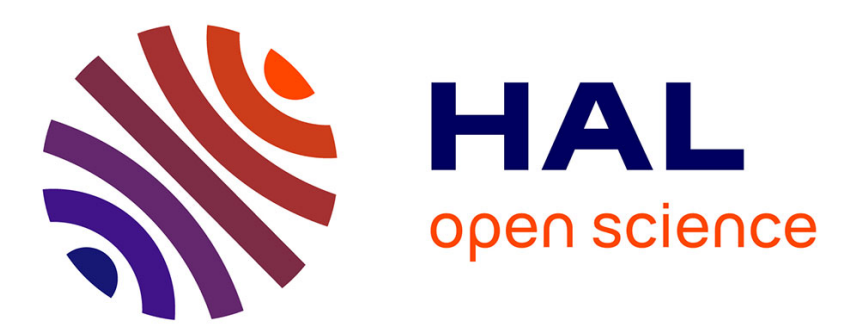

\title{
Effects Of Thermal Exchange On Material Flow During Steel Thixoextrusion Process
}

Eric Becker, Guochao Gu, Laurent Langlois, Raphaël Pesci, Régis Bigot

\section{To cite this version:}

Eric Becker, Guochao Gu, Laurent Langlois, Raphaël Pesci, Régis Bigot. Effects Of Thermal Exchange On Material Flow During Steel Thixoextrusion Process. International Conference on Advances in Materials and Processing Technologies, Oct 2010, Paris, France. pp.751, 10.1063/1.3552539 . hal01084417

\section{HAL Id: hal-01084417 https://hal.science/hal-01084417}

Submitted on 19 Nov 2014

HAL is a multi-disciplinary open access archive for the deposit and dissemination of scientific research documents, whether they are published or not. The documents may come from teaching and research institutions in France or abroad, or from public or private research centers.
L'archive ouverte pluridisciplinaire HAL, est destinée au dépôt et à la diffusion de documents scientifiques de niveau recherche, publiés ou non, émanant des établissements d'enseignement et de recherche français ou étrangers, des laboratoires publics ou privés. 


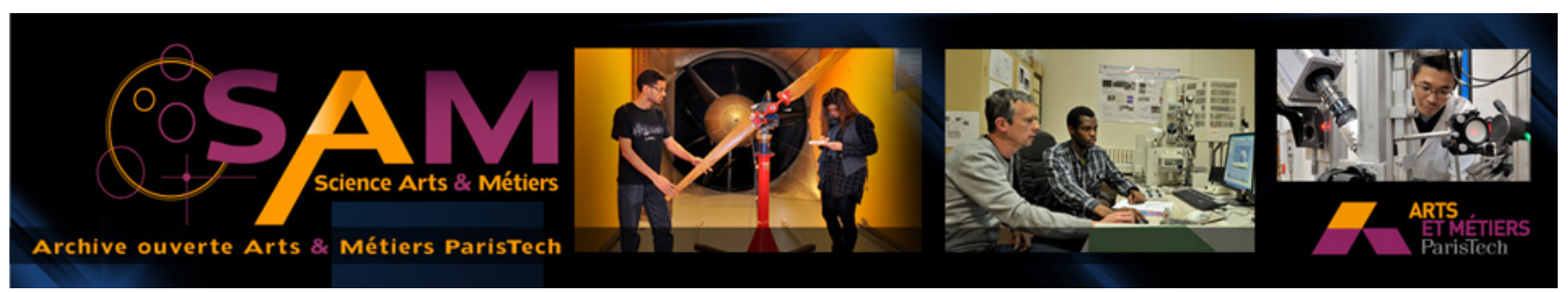

\section{Science Arts \& Métiers (SAM)}

is an open access repository that collects the work of Arts et Métiers ParisTech researchers and makes it freely available over the web where possible.

This is an author-deposited version published in: http://sam.ensam.eu

Handle ID: .http://hdl.handle.net/10985/8947

\section{To cite this version :}

Eric BECKER, Guochao GU, Laurent LANGLOIS, Raphaël PESCI, Régis BIGOT - Effects Of Thermal Exchange On Material Flow During Steel Thixoextrusion Process - In: International Conference on Advances in Materials and Processing Technologies, France, 2010-10-24 - AMPT $2010-2010$ 


\title{
Effects Of Thermal Exchange On Material Flow During Steel Thixoextrusion Process
}

\author{
Becker Eric $^{\mathrm{a}}$, Gu Guochao ${ }^{\mathrm{a}}$, Langlois Laurent ${ }^{\mathrm{a}}$, Pesci Raphaël ${ }^{\mathrm{b}}$, Bigot \\ Régis $^{\mathrm{a}}$ \\ ${ }^{a}$ Laboratoire de Conception Fabrication Commande (LCFC) - ENSAM - 4, rue Augustin Fresnel - \\ F57070 Metz Technopôle - France. \\ ${ }^{b}$ Laboratoire de Physique et Mécanique des Matériaux (LPMM) - ENSAM - 4, rue Augustin Fresnel - \\ F57070 Metz Technopôle - France.
}

\begin{abstract}
Semi-solid processing is an innovative technology for near net-shape production of components, where the metallic alloys are processed in the semi-solid state. Taking advantage of the thixotropic behavior of alloys in the semi-solid state, significant progress has been made in semi-solid processing. However, the consequences of such behavior on the flow during thixoforming are still not completely understood. To explore and better understand the influence of the different parameters on material flow during thixoextrusion process, thixoextrusion experiments were performed using the low carbon steel C38. The billet was partially melted at high solid fraction. Effects of various process parameters including the initial billet temperature, the temperature of die, the punch speed during process and the presence of a Ceraspray layer at the interface of tool and billet were investigated through experiments and simulation. After analyzing the results thus obtained, it was identified that the aforementioned parameters mainly affect thermal exchanges between die and part. The Ceraspray layer not only plays a lubricant role, but also acts as a thermal barrier at the interface of tool and billet. Furthermore, the thermal effects can affect the material flow which is composed of various distinct zones.
\end{abstract}

Keywords: Semi-solid, thixoextrusion, thermal exchange, low carbon steel grade C38.

PACS: Replace this text with PACS numbers; choose from this list:

\section{INTRODUCTION}

Semi-solid metal forming or thixoforming, shaping metal components in semi-solid state, is an innovative near net-shape forming process [1] which allows manufacturing parts with complex geometry, giving high mechanical properties and reducing forming steps compared with conventional die- casing and forging processes.

It has been forty years since the original experiment which led to the interest in semi-solid metal processing (SSM) studied by researchers at the MIT [2]. Up to now, thixoforming has established itself as a scientifically sound technology in the production of aluminum and magnesium alloys. However, the thixoforming process of Fe-based alloys is still at laboratory stage, due to the high process temperature involved, suitable tool materials, heating and controlling of billets and also microstructural observation, although some possibilities have been demonstrated by researchers. The width of the semi-solid interval [3], the evolution of the microstructure in the semi-solid state [4] as well as the modeling of semi-solid 
behavior and material flow [5] have been investigated by many researchers. The possibility of performing thixoforging experiments on an inductively heated rolling bar has been illustrated in work [6].

Thermal exchange during thixoextrusion process is very important, since it controls the material flow and the evolution of microstructure. It is necessary to better understand it with the complete analysis of thixoforging process parameters such as steel grade, punch speed, billet and tool temperature.

In this work, the effects of various process parameters on material flow during thixoextrusion process are investigated and the effects of thermal exchange on the different aspects of the final parts are discussed regarding thixoextrusion experiments and simulation. C38 low carbon steel was used for this study.

\section{EXPERIMENTAL PROCEDURE}

\section{Material}

The C38 low carbon steel used was produced by hot rolling. Its chemical composition is given in Table 1 . The billet size was $45 \mathrm{~mm}$ in height and $30 \mathrm{~mm}$ in diameter.

TABLE 1. Chemical composition of the C38 low carbon steel (weight \%, iron balance).

\begin{tabular}{lccccccccc}
\hline $\mathbf{C}$ & $\mathbf{M n}$ & $\mathbf{P}$ & $\mathbf{S}$ & $\mathbf{S i}$ & $\mathbf{A l}$ & $\mathbf{N}$ & $\mathbf{N i}$ & $\mathbf{C r}$ & $\mathbf{C u}$ \\
\hline 0.418 & 0.751 & 0.010 & 0.021 & 0.198 & 0.021 & 0.065 & 0.077 & 0.144 & 0.133 \\
\hline
\end{tabular}

\section{Methods and Equipment}

Due to its repeatability and the lesser billet heating time, induction heating technique was used in our experiments. In the aim of reducing heat loss during the transfer of the billet and retaining the billet shape, this system had the induction coil located above the die gate. In order to maintain a constant punch speed during forming, a shock absorption system for the punch was developed and integrated into the tolls to avoid material deformation during the slowdown in punch speed. The experimental device is illustrated in figure 1 [7].

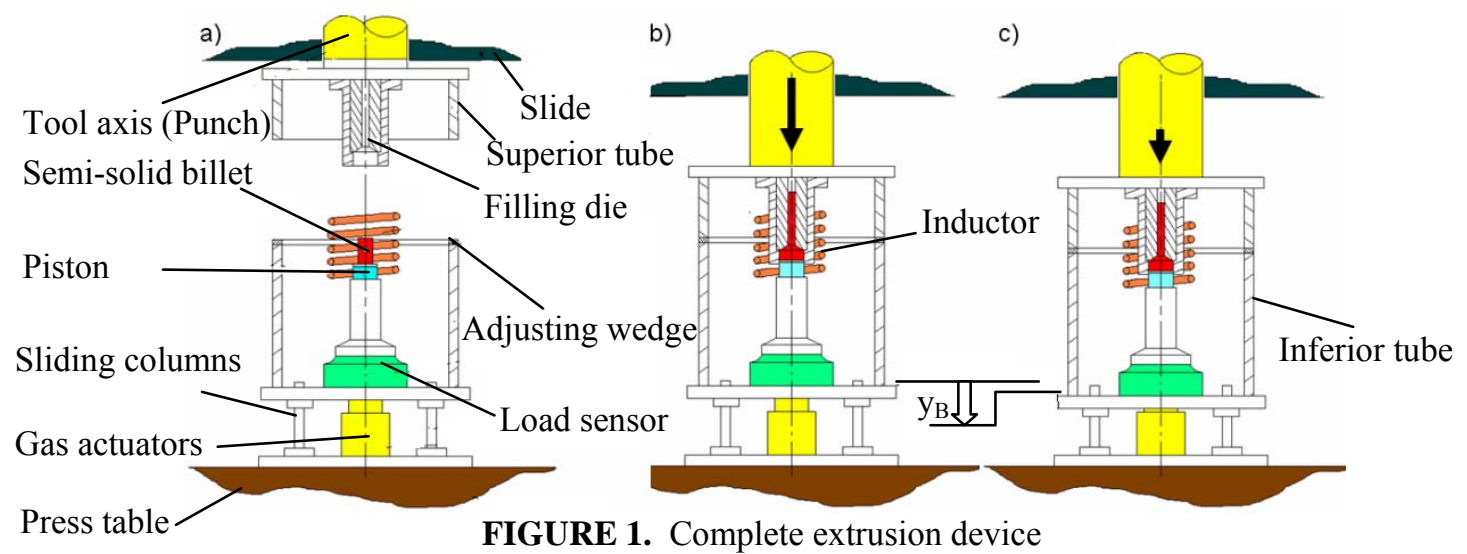


(a) Induction heating step - (b) End of thixoextrusion - (c) End of thixoforging

In these experiments, four thermocouples were used to measure the temperature at various positions as shown in figure $2 \mathrm{a}$. A relatively uniform temperature distribution was obtained, having 1 to $10^{\circ} \mathrm{C}$ difference between the center and the surface of the billet, with the heating cycle consisting in several power stages separated by dwell time (figure $2 \mathrm{~b}$ ). These conditions provided a homogeneous microstructure with a grain size of about $200 \mu \mathrm{m}$ (figure 3 )

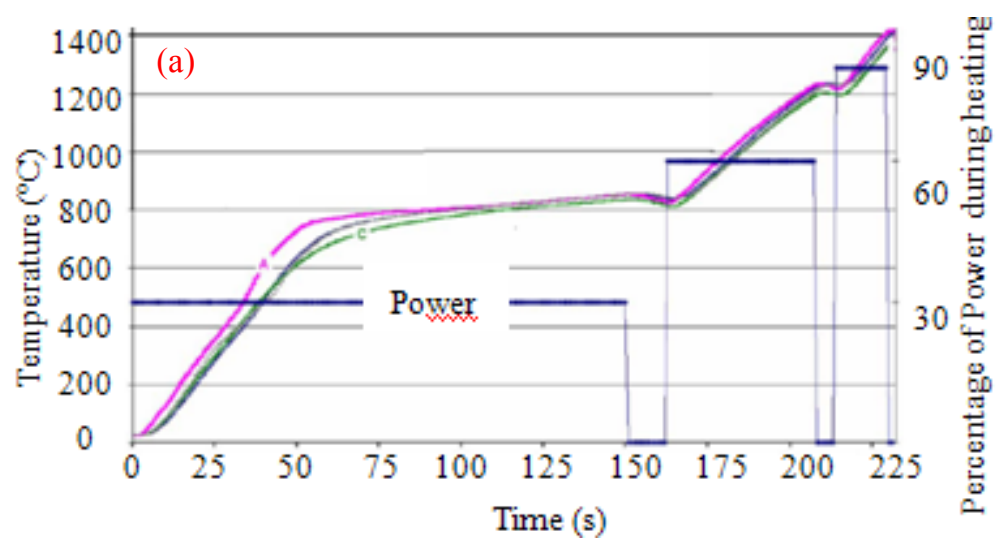

(b)

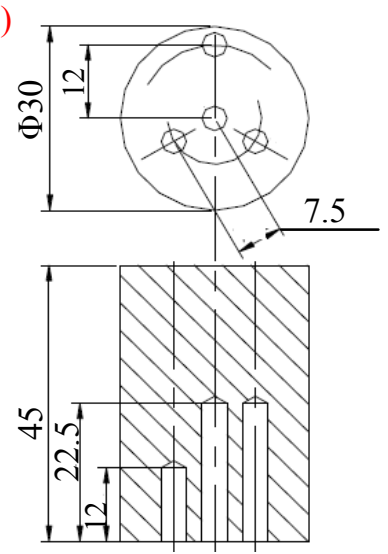

FIGURE 2. (a) Heating cycle - (b) Position of thermocouples

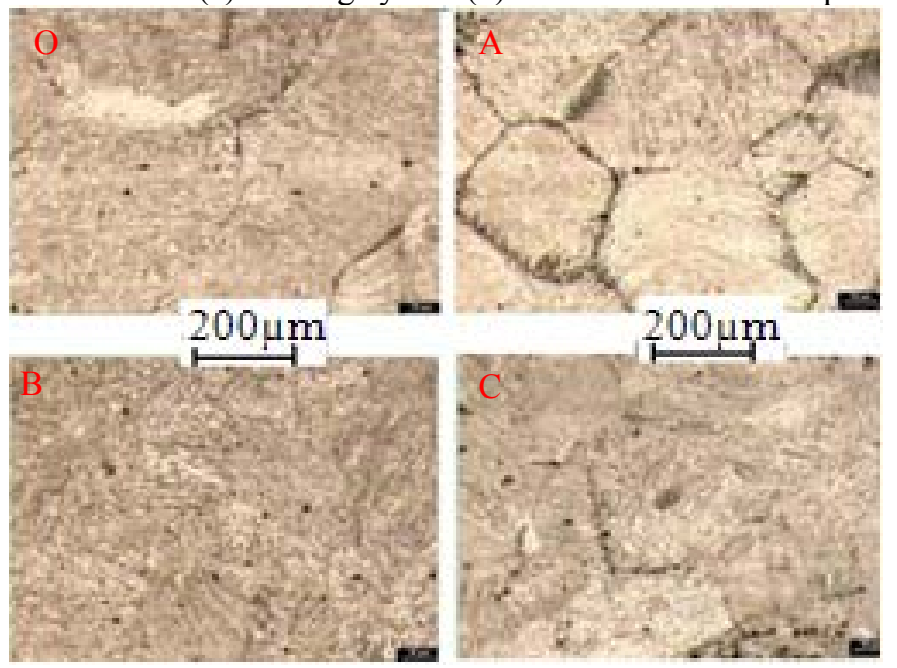

FIGURE 3. Microstructure obtained in 4 points (quenching from $1420^{\circ} \mathrm{C}$ ) - Etched with $2 \%$ nital

\section{RESULTS}

Experiments have been performed on $\mathrm{C} 38$ steel grade billets under various process conditions. Figure 4 presents the results of various experiments. Here, P.S means punch speed, and D.T. means die temperature.

As illustrated in figure 4, for the same punch speed and die temperature, the maximum force decreased with increasing initial billet temperature. When forming the part with an initial billet temperature of $1451^{\circ} \mathrm{C}$ and a cold die $\left(30^{\circ} \mathrm{C}\right)$, the maximum load decreased with increasing punch speed, and the maximum force for extrusion process increased when forming the part with a warm die $\left(400^{\circ} \mathrm{C}\right)$. In addition, the part could be formed with the same load under different process parameters; for example, 
when comparing the experiment with a die temperature of $30^{\circ} \mathrm{C}$, a punch speed of $200 \mathrm{~mm} / \mathrm{s}$ and an initial billet temperature of $1420^{\circ} \mathrm{C}$, with the experiment with a die temperature of $400^{\circ} \mathrm{C}$, a punch speed of $40 \mathrm{~mm} / \mathrm{s}$ and an initial billet temperature of $1451^{\circ} \mathrm{C}$, both of the maximum loads needed were $210 \mathrm{kN}$.

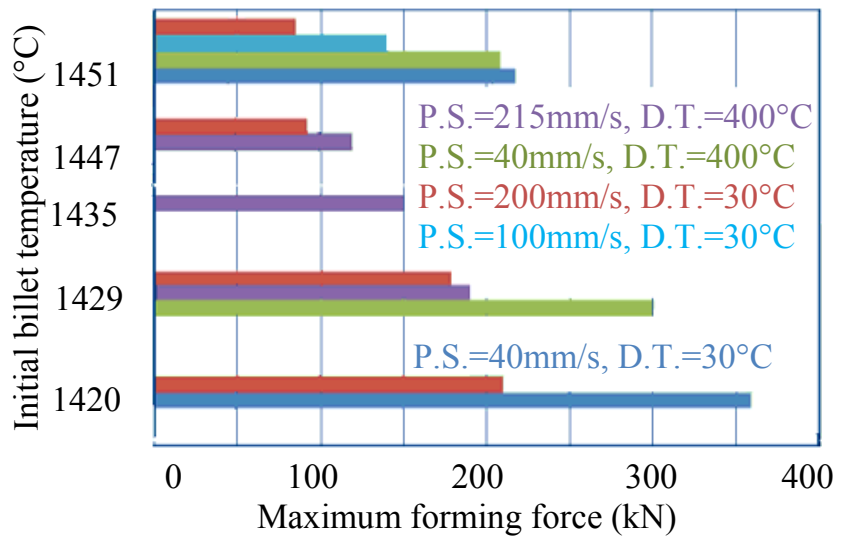

FIGURE 4. Influence of speed, billet temperature and die temperature on forming force

The load versus displacement curves of two extrusion experiments are exhibited in figure 5 to show the effect of the Ceraspray(C) layer put on the dies on the forming force. The load first increased slowly with the displacement until the die cone was filled; then it increased strongly up to a maximum value which corresponded to the step of filling the die with the smaller diameter. The load fluctuation at the end of extrusion was due to the "hydraulic" inertia. The forming force was reduced by $25 \%$ with the existence of Ceraspray ${ }^{C}$ layer on the die surfaces. Two functions of Ceraspray(C) layer were assumed: a reduction of friction effect and of heating losses.

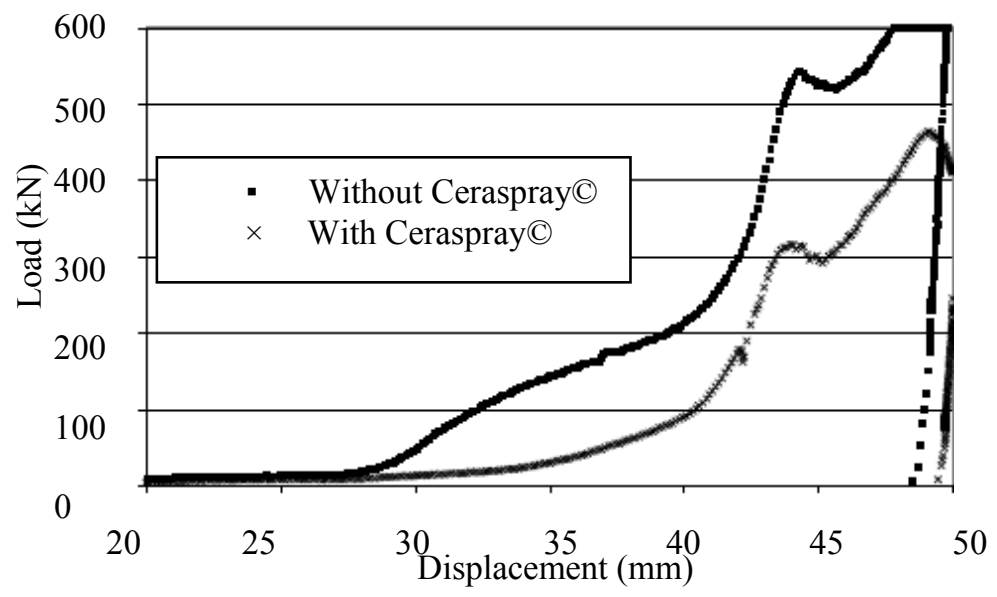

FIGURE 5. Load-displacement curves during the thixoextrusion with and without the Ceraspray( layer (punch speed of $40 \mathrm{~mm} / \mathrm{s}$, initial billet temperature of $1429^{\circ} \mathrm{C}$; press without damping device)

\section{DISCUSSION}

The results described above showed the effects of initial billet and die temperature, punch speed and the presence of the Ceraspray(C) layer on the forming force. As the experiments were non-isothermal, heat exchange varied with the forming conditions 
during extrusion process. The temperature variations due to the forming time and heat exchange generated an evolution of viscosity, disagglomeration and stress, and consequently of the flow of the material and the final properties of the part.

\section{Shapes of Final Parts}

Several parts extruded under various process conditions are shown in figure 6; with a relative low punch speed and a cold die, a critical initial billet temperature around $1437^{\circ} \mathrm{C}$ was found. A heterogeneous flow was observed with initial billet temperature above $1437^{\circ} \mathrm{C}$. Bad surfaces with wrenching and cracking which revealed a liquid/solid phase separation were observed on parts extruded with a higher initial billet temperature. This separation phenomenon was also presented in work [8] for other steel grades. Meanwhile, when a warm die and Ceraspray $\subset$ layer were employed for the extrusion of a billet at $1445^{\circ} \mathrm{C}$, a correct shape was obtained, which meant that the critical temperature was moved to a higher value. The reason could be due to less heat loss during extrusion which made the liquid distribution and material morphology more uniform in the cross section, which resulted in a homogeneous material flow.

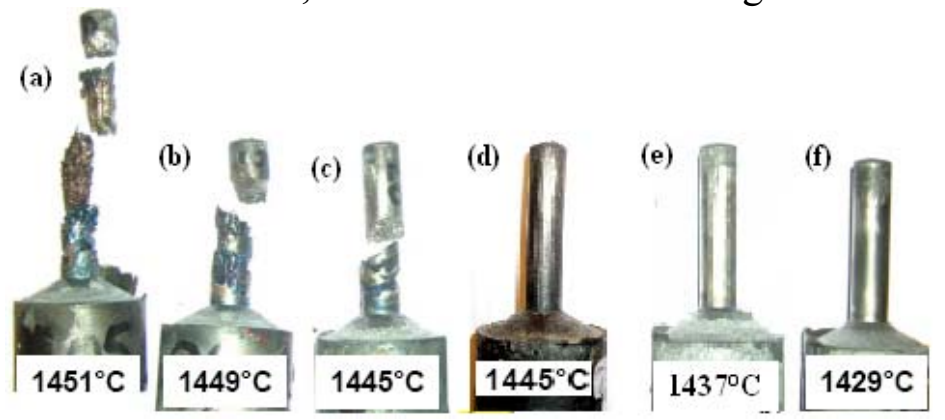

FIGURE 6. Shape of final parts formed under various process conditions

Parts (a), (b), (c), (e) and (f) were formed using a "cold" die and a punch speed of $215 \mathrm{~mm} / \mathrm{s}$. Part (d) was formed using a "warm" die and a punch speed of $215 \mathrm{~mm} / \mathrm{s}$

This assumption was confirmed by performing simulations of extrusion process with two different process conditions: extruding an initial billet temperature with a punch speed of $40 \mathrm{~mm} / \mathrm{s}$, using cold and warm dies, as shown in figure 7 . The heat transfer coefficient used was $20 \mathrm{~kW} \cdot \mathrm{m}^{-2} \cdot \mathrm{K}^{-1}$. The temperature at the interface was much higher when using a warm die than a cold one. That means the heat losses were lower with a warm die than with a cold one. Using a warm die and a Ceraspray@ layer can reduce the heat losses, thereby reducing the phase separation, and consequently improving the final part shape and surface quality. 

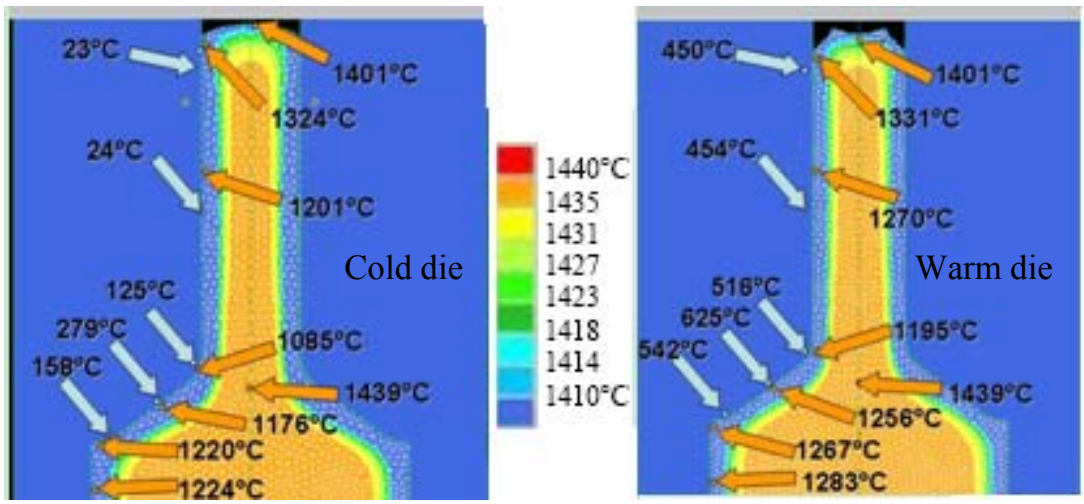

FIGURE 7. Temperature distribution during the process

\section{Forming Force}

Forming force increased with decreasing initial billet temperature. This result is similar to that found in many papers dealing with semi-solid structures, such as aluminum alloys and steels [9]; it is attributed to the increase of liquid volume fraction. When the initial billet temperature is increased, the liquid volume fraction increases which results in a lower forming force. As expected, an increase in the press velocity resulted in lower required forces, because there was less time for cooling and solidification. Compared with conventional extrusion process using the same forming dies and billet dimensions, the average extrusion force required in the thixoextrusion experiments was very low, though a continuous rise of the required force was detected in thixoextrusion. It's worth noting that a massive shell formation defect was observed in the work of [10] when performing a thixoextrusion on a high liquid fraction billet. The defect was generated by reason of the reduction billet temperature when the billet material came in contact with the extrusion channel wall.

\section{CONCLUSIONS}

Extrusion trials were performed on a semi-solid C38 steel with high solid fractions. The quality of thixoextruded parts depends on the forming speed, initial billet and tool temperature. Thermal exchange plays an important role in thixoextrusion process. A part with good quality can be obtained with less thermal exchange during thixoextrusion. A warm die coated with Ceraspray $(\mathrm{C}$ layer and higher punch speed help to reduce the thermal exchange between tool and material. At a suitable initial billet temperature, a part with good surface quality can be thixoextruded. Resultant microstructure evolution and mechanical properties will be studied in the future.

\section{REFERENCES}

1. P. Kapranos, P.J. Ward, H.V. Atkinson, D.H. Kirkwood, Materials and Design 21, 387-394 (2000).

2. M.C. Flemings, Metallurgical and Materials Transactions A 22, 957-981(1991).

3. W. Püttgen and W. Bleck, Steel Res. Int. 75, 531-536 (2004).

4. W. Püttgen, B. Hallstedt, W. Bleck, J.F. Löffler, P.J. Uggowitzer, Acta Materiallia 55, 1033-1042 (2007) . 
5. V. Favier, R. Bigot, and P. Cezard, Material Science and Engineering A 517, 8-16 (2009)

6. E. Becker, " Investigations expérimentales et numériques pour l'identification des paramètres clefs du procédé de thixoforgeage de l'acier sur le produit mis en forme ", Ph.D. Thesis, l'École Nationale Supérieure d'Arts et Métiers - ENSAM, 2008.

7. E. Becker, V. Favier, R. Bigot, P. Cezard and L. Langlois, Materials Processing Technology 210, 1482-1492 (2010).

8. R. Kopp, H. Shimahara, J.M. Schneider, D. Kurapov, R. Telle, S. Munstermann, E. Lugscheider, K. Bobzin and M. Maes, Steel Research International 75, 569-576 (2004).

9. F. Knauf, R. Baadjou, G. Hirt, R. Kopp, S. Munstermann and R. Telle, "Thixoextrusion," in Thixoforming- Semi-solid Metal Processing, edited by G. Hirt and R. Kopp, Weinheim: WILEYVCH Verlag GmbH \& Co. KGaA, 2009, pp. 411-442.

50. F. Knauf, G. Hirt, P. Immich,and K. Bobzin, "Influence of tool geometry, tool coating and process parameters in thixoextrusion of steel" in $10^{\text {th }}$ ESAFORM conference on material formingr-2007, edited by E. Cueto et F Chinest, AIP Conference Proceedigs 907, American Institute of Physics, Melville, NY, 2007, pp. 1173-1178. 